\title{
Enzymatic Browning of Thompson Seedless Grapes Results in Changes of Colour of Dried Raisins
}

\author{
J. N. Kalbhor, S. R. Bhagwat*, J. M. Khilari, T. S. Shelake and S. Y. Patil
}

$R \& D$ Unit, Maharashtra Grape Growers Association Manjari Farm, Pune - 412307, India

*Corresponding author

Keywords

Raisin, Enzymatic Browning

Article Info

Accepted:

15 January 2021

Available Online:

10 February 2021
The present study was conducted to examine the effect of enzymatic browning on Thompson Seedless dried raisins. Raisin browning is the biochemical process in which plant tissue occurs brown colour when exposed to oxygen. Different treatments of Ascorbic Acid (0.5\%), Chlorinated water (100 ppm), Metabisulphite $0.5 \%$, Cysteine $0.5 \%$ and farmers practice were given as a pre-drying treatment on quality of dried on-vine (DOV) raisins prepared from seedless grape variety i.e. Thompson seedless.Outcomes of the results reveals that the samples treated with Ascorbic Acid shows lowest colour change as compare to other samples, so they have higher quality raisins. In this treatment out of $1 \mathrm{~kg}$ treated raisin sample was distributed as Green, light green, light brown, and Dark brown category. Ttreatment 2 i.e. Ascorbic Acid0.5 $\%$ is better than other treatments after drying and grading the raisins in different category like pale yellow, light yellow, light brown colour and dark brown colour. Impact of this enzymatic browning study of each treatment was carried out in traditional grape drying unit at MRDBS and observation to be recorded after drying. Aaverage percentage recorded in $1 \mathrm{~kg}$ raisins to be sort out at different colour formation and their quality. The outcome of the study reveals that treatment 2 is better and its browning percentage is recorded as $38.48 \%$ in comparison to other treatments i.e. $32.33 \%, 18.88 \% 13.60 \%$ and $24.03 \%$ respectively.

\section{Introduction}

Grape (Vitis vinifera L.) is one of the important fruit crops cultivated widely in temperate and subtropical climates. Even though, the grape originated in temperate regions, it performs equally well in tropical climate in India, where they are grown as an evergreen vine without undergoing dormancy.
Raisins are a one of the favourite dried fruit throughout the world having good sources of essential vitamins and minerals (Chadha and Shikhamani, 1999). The quality of raisins is mainly perceived by their colour. Greencoloured raisins are considered as the best quality raisins whereas brown/dark-coloured raisins possess poor quality. Raisin colour is affected by different factors like grape variety, 
pre-treatments to grape berries, drying method, drying conditions, etc. Grape (Vitis vinifera L.) is an important commercial fruit crop, which grows in a wide range of climatic conditions. Dried grapes, commonly known as raisins, are of a great economic importance Grape (Vitis vinifera) is basically a subtropical crop (Deoreyappa and Gowda, 1998). However, in India, grapes are cultivated for their excellence also under tropical conditions. In India, Grapes are cultivated in an area under 138 thousand ha with production of 2980 thousand MT during 2017-18. Grape is mainly cultivated in Maharashtra followed by Karnataka, Tamil Nadu, Mizoram and Andhra Pradesh. Some northern states viz.; Punjab, Himachal Pradesh and Jammu and Kashmir are also producing grapes. While, 71 per cent of grape produced is available for table purpose and nearly 27 per cent is dried for raisin making (Sharma et al., 2017), 1.5 per cent for winemaking and 0.5 per cent is used for juice (Adsule et al., 2012). In India, nearly 17 to 20 per cent grapes are dried for raisin making from the varieties viz., Thompson Seedless and its clones viz., Tas-A-Ganesh, Sonaka and ManikChaman (Adsule et al., 2008). In India, raisin is mainly produced in Sangli, Solapur and Nasik districts of Maharashtra and Bijapur district of Karnataka state.

The technique of raisin production in India is mostly based on the dipping of the grape bunches in emulsion having 2.5 per cent potassium carbonate and 1.5 per cent ethyl oleate for a duration of 2 to 4 minutes, and subsequent shade drying in open tier system (Adsule et al., 2012). The dipping oil treatment alone induced soft texture, but it led to the development of brown rather greenish colour. Green coloured raisins are highly valued for their fresh, attractive green colour, sweet flavour and sold for two to three times the price of sun-dried raisins. Application of antioxidants like ascorbic acid and benzyl adenine effectively reduced browning and increased the storage period of many fruits. Green colour is one of the major concerns in raisin production; hence, extensive research is necessary to find the effect of various concentrations of antioxidants with alkaline emulsion of ethyl oleate as a pre-drying treatment on colour retention and quality of DOV raisins prepared from seedless varieties of grapes (Venkatram et al., 2017)

Coloured pigment melanin, being produced result of biochemical reaction the enzymatic and non-enzymatic reaction are responsible for colour change of the raisin at the time of grape drying endogenous phenolic compounds come into contact with polyphenol oxidize (PPO) which initiates enzymatic browning and this reaction can occur in the presence of molecular oxygen. PPO is separated from the main grape phenolic substrate in healthy berry tissue. As a consequence of physical damage during drying due to berry shrinkage and tissue collapse by virtue water loss the PPO enzymes comes to contact with grape phenolic substrate mainly trans- caftaric acid (transceffeoyl tartaric acid) also colour formation is the primary characteristic of maillard reaction (Ranveer et al., 2010). The drying conditions during green raisin production include shade drying, low relative humidity and moderate air temperature (below $40^{\circ} \mathrm{C}$ ). Raisin quality depends on size of the berry, berry colour uniformity, brilliance of berry colour, berry surface condition, skin texture, pulp chemical composition and presence of any foreign matter. However, for retention of green colour in the grape berries during drying there are some basic requirements which include air temperature $25-35^{\circ} \mathrm{C}$, relative humidity $25-$ $35 \%$, mean, moderate air velocity and no direct exposure to sunlight. Besides, greencoloured raisins can also be obtained by employing suitable treatments during grape drying. Sharma et al., (2016) reported the significance of pre-treatments on grape berries 
for producing lighter-coloured raisins. One of the major factors influencing raisin colour is the discolouration or browning during drying. Grapes lose their natural green colour and turn brown due to a combi nation of browning reactions during drying, which may be enzymatic and non-enzymatic. Reducing sugars and ascorbic acid also contribute to browning reactions.

Different chemical treatments for reducing browning reactions in foods have been documented, including application of ascorbic acid in fresh cut fruits and vegetables.

Ascorbic acid is an antioxidant and also a GRAS (generally recognized as safe) chemical. Use of ascorbic acid and its derivatives as anti-browning agents has been documented in several studies in concentrations ranging from $0.5 \%$ to $4 \%$.

Efficacy of antioxidants such as benzyl adenine and ascorbic acid in reducing the browning of raisins has been studied earlier. Raisins produced from Thompson Seedless grapes after treatment with ethyl oleate and ascorbic acid (1000 ppm) solutions showed the lowest browning and increased percentage of green-coloured raisins (Sharma et al., 20016). Considering the importance of raisins colour in terms of economic gains as well as nutritional value, the present study was carried out to evaluate the effect of enzymatic browning in changes of colour of dried raisins.

\section{Materials and Methods}

The field Experiment was carried out at Maharashtra Rajya Draksh Bagaitdar Sangh in Sangli during the year 2017-2018.The traditional shade drying method was adopted for grape drying.

The experimental location falls under semiarid tropical climatic zone, having annual rainfall of $800 \mathrm{~mm}$. The selected grape bunches were trimmed by removing the small, damaged, infected and immature berries with scissors on fruiting canes then wrapped on wires supported by interconnected Y-trellis and fruiting canes cut (cane severance) at fruit maturity of $>21$ oBrix.

The bunches are dried on the vine (DOV) after severing the fruit bearing canes and leaving the canes that will carry the next year's crop. The fruit bearing canes are then sprayed with Ascorbic Acid (0.5\%), Chlorinated water (100 ppm), Metabisulphite 0.5\%, Cysteine 0.5 $\%$ and farmers practice.

The treated grape berries were then dipped with water solution containing $2.5 \%$ potassium carbonate and $1.5 \%$ ethyl oleate. The $\mathrm{pH}$ of the solution was adjusted to 11 while adding potassium carbonate. A dipping time of 3 minutes' duration has been recommended.

After drying the raisins are separated on the basis of their visual appearance as shown in Image 1. Impact of this enzymatic browning in each treatment was then recorded.

\section{Results and Discussion}

India has made tremendous strides in improving the horticultural outputs through use of recent agro-technologies. The season during which trial was conducted was very dry with moderate temperature. The observations on percentage of enzymatic browning were presented in Table 1 and Fig. 1.

According to above results it is determined that the samples treated with Ascorbic acid shows lowest colour change as compare to other samples, so they have higher quality raisins. In this treatment out of $1 \mathrm{~kg}$ treated raisin sample was distributed as Green, light green, light brown, and Dark brown category. 
Table.1 Effect of Agrochemicals in enzymatic browning in Raisin Thompson Seedless grapes

\begin{tabular}{|c|c|c|c|c|c|c|c|c|}
\hline Treatment & $\begin{array}{c}\text { Pale } \\
\text { Yellow (g) } \\
\text { in 1 kg }\end{array}$ & $\begin{array}{c}\text { Light } \\
\text { Yellow (g) } \\
\text { in 1 kg }\end{array}$ & $\begin{array}{c}\text { Light } \\
\text { Brown (g) } \\
\text { in 1 kg }\end{array}$ & $\begin{array}{c}\text { Dark } \\
\text { Brown (g) } \\
\text { in 1 kg }\end{array}$ & $\begin{array}{c}\text { Pale } \\
\text { Yellow } \\
\text { \% }\end{array}$ & $\begin{array}{c}\text { Light } \\
\text { Yellow } \\
\text { \% }\end{array}$ & $\begin{array}{c}\text { Light } \\
\text { Brown } \\
\text { \% }\end{array}$ & $\begin{array}{c}\text { Dark } \\
\text { Brown } \\
\text { \% }\end{array}$ \\
\hline $\begin{array}{c}\text { T1- (Chlorinated } \\
\text { water @ 100 ppm) }\end{array}$ & 323.29 & 347.19 & 208.12 & 121.40 & 32.33 & 34.72 & 20.81 & 12.14 \\
\hline $\begin{array}{c}\text { T2-(Ascorbic } \\
\text { Acid @ 0.5 \%) }\end{array}$ & 384.81 & 309.51 & 193.70 & 111.98 & 38.48 & 30.95 & 19.37 & 11.20 \\
\hline $\begin{array}{c}\text { T3- } \\
\text { (Metabisulphite) }\end{array}$ & 188.80 & 356.17 & 265.60 & 189.43 & 18.88 & 35.62 & 26.56 & 18.94 \\
\hline $\begin{array}{c}\text { T4- (Cysteine @ } \\
\text { 0.5 \%) }\end{array}$ & 135.95 & 199.65 & 406.57 & 257.83 & 13.60 & 19.96 & 40.66 & 25.78 \\
\hline $\begin{array}{c}\text { T5- (Farmer } \\
\text { Practice) }\end{array}$ & 240.34 & 461.87 & 207.65 & 90.16 & 24.03 & 46.19 & 20.77 & 9.02 \\
\hline C.D @ 5 \% & $\mathbf{4 9 . 5 6}$ & $\mathbf{5 4 . 0 0}$ & $\mathbf{5 5 . 5 0}$ & $\mathbf{4 9 . 1 2}$ & $\mathbf{4 . 9 6}$ & $\mathbf{5 . 4 0}$ & $\mathbf{5 . 5 5}$ & $\mathbf{4 . 9 1}$ \\
\hline C.V \% & $\mathbf{1 2 . 6 3}$ & $\mathbf{1 0 . 4 6}$ & $\mathbf{1 4 . 0 5}$ & $\mathbf{2 0 . 6 7}$ & $\mathbf{1 2 . 6 3}$ & $\mathbf{1 0 . 4 7}$ & $\mathbf{1 4 . 0 5}$ & $\mathbf{2 0 . 6 8}$ \\
\hline
\end{tabular}

Table.2 Effect of chemicals on raisin colour intensity with the help of UV Spectrometer

\begin{tabular}{|c|c|c|c|c|}
\hline Treatment & Dark brown & Light Brown & Light Green & Green \\
\hline T-1 & 0.04 & 0.04 & 0.06 & 0.05 \\
\hline T-2 & 0.05 & 0.04 & 0.04 & 0.05 \\
\hline T-3 & 0.08 & 0.10 & 0.07 & 0.08 \\
\hline T-4 & 0.07 & 0.10 & 0.09 & 0.09 \\
\hline T-5 & 0.11 & 0.07 & 0.07 & 0.09 \\
\hline
\end{tabular}


Fig.1

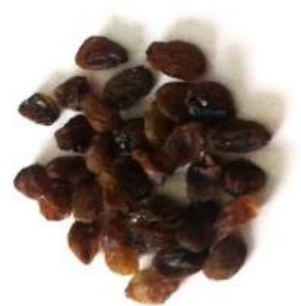

Dark Brown

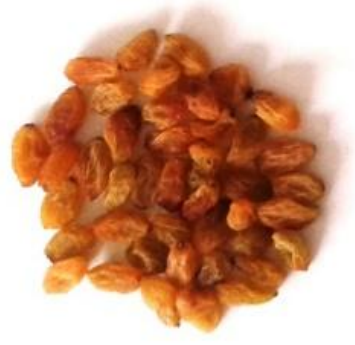

Light Brown

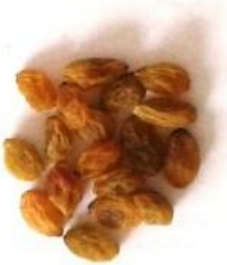

Light Green

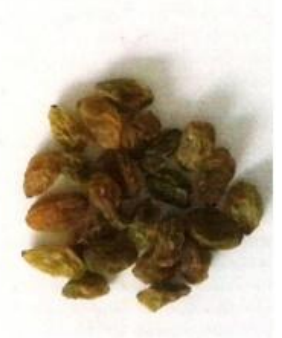

Green
The data showed that the application of various chemicals significantly increases the browning and quality raisins. Among the all treatments Ascorbic Acid $(0.5 \%)$, Chlorinated water $(100 \mathrm{ppm})$, Metabisulphite $0.5 \%$, Cysteine $0.5 \%$ and farmers practice, spraying with Knap- sack sprayer shows maximum brownness in compared to control and other treatments. Effect of various chemicals on raisin colour intensity was also determined. Raisin samples (5 g) were soaked in distilled water $(100 \mathrm{~mL})$ for 3 hours with occasional swirling. The supernatant was filtered through Whatmann No. 41 filter paper. The absorbance of the supernatant filtrate was measured by UV/VIS Spectrophotometer at $420 \mathrm{~nm}$ (Table 2).

Colour is one of the most important characteristic of raisin that determines its quality parameters. Light golden to amber colour characteristics are generally preferable by both local and export markets. By concluding the current research, it was found that treatment 2 i.e. Ascorbic Acid @ $0.5 \%$ )is the better than other treatments after drying grading the raisins in different category like pale yellow, light yellow, light brown colour and dark brown colour. But we have to need research and study other chemicals they are shown better result on raisin browning in grapes in future.

\section{References}

Adsule, P.G., Karibasappa, G.S., Banerjee, K. and Mundankar, K. (2008). Status and prospects of raisin industry in India. Acta Hort., 785: 507-14.

Adsule, P.G., Sharma, A.K., Banerjee, K. and Karibasappa, G.S. (2012). Raisin industry in India: adoption of good drying practices for safe raisins. NRC for Grapes, Bulletin, 85: 974/975/976, 209-15.

Chadha, K. L. and Shikhamany, S. D. (1999). The Grape- Improvement, Production and Post-Harvest Management. Malhotra Publishing House, New Delhi, India, Pp. 338-380.

Deoreyappa, I.N. and Gowda (1998). Advances in improvement of raisin quality. Indian Fd. Ind., 17(4): 218 223.

Ranveer R.C., Pawan V.N., Sakhale B.K. and Sahoo A.K. (2010). Effect of storage conditions on the residual polyphenol oxidase (PPO) activity of raisins. International Journal of Agricultural Sciences, 6(1):61-64.

Sharma, A.K., Banerjee, K., Ramteke, S.D. et al., (2016). Evaluation of Ascorbic Acid and Sodium Metabisulfite Applications for Improvement in 
Raisin Quality. Proc. Natl. Acad. Sci., India, Sect. B Biol. Sci. 86, 637-641.

Sharma, A.K., Ramteke, S.D., MaishaLahoti and Adsule, P.G. (2012). Effect of ascorbic acid and sodium metabisulphite application on Thompson Seedless grapes bunches during drying. Proceeding of the 5th
Indian Horticulture Congress, Ludhiana, India, Pp. 435.

Venkatram, A., Padmavathamma, A.S., Manorama, K. and Vijaya, D. (2017). Changes in quality of dried-on-vine (DOV) raisins as influenced by predrying treatments and seedless varieties of grape (Vitis vinifera L.). Agric. Update. 12: 9-17.

\section{How to cite this article:}

Kalbhor, J. N., S. R. Bhagwat, J. M. Khilari, T. S. Shelake and Patil, S. Y. 2021. Enzymatic Browning of Thompson Seedless Grapes Results in Changes of Colour of Dried Raisins. Int.J.Curr.Microbiol.App.Sci. 10(02): 1661-1666. doi: https://doi.org/10.20546/ijcmas.2021.1002.196 